\title{
Vitreoscilla hemoglobin promotes Salecan production by Agrobacterium sp. ZX09*
}

\author{
Yun-mei CHEN, Hai-yang XU, Yang WANG, Jian-fa ZHANG, Shi-ming WANG ${ }^{\dagger \neq}$ \\ (Center for Molecular Metabolism, Nanjing University of Science \& Technology, Nanjing 210094, China) \\ †E-mail: bioeng@mail.njust.edu.cn
}

Received Apr. 29, 2014; Revision accepted July 22, 2014; Crosschecked Oct. 11, 2014

\begin{abstract}
Salecan is a novel exopolysaccharide produced by the strain Agrobacterium sp. ZX09, and it is composed of only glucose monomers. The unique chemical composition and excellent physicochemical properties make Salecan a promising material for applications in coagulation, lubrication, protection against acute liver injury, and alleviating constipation. In this study, we cloned the Vitreoscilla hemoglobin gene into a broad-host-range plasmid pCM158. Without antibiotic selection, there was negligible loss of the plasmid in the host Agrobacterium sp. ZX09 after one passage of cultivation. The expression of Vitreoscilla hemoglobin was demonstrated by carbon monoxide (CO) difference spectrum. The engineered strain Agrobacterium sp. ZX09 increased Salecan yield by 30\%. The other physiological changes included its elevated respiration rate and cellular invertase activity.
\end{abstract}

Key words: Salecan, Vitreoscilla hemoglobin, Agrobacterium sp. ZX09, Invertase, Respiration rate doi: 10.1631 jzus.B1400123

Document code: A

CLC number: Q939.97

\section{Introduction}

Among the polysaccharides produced by bacteria, $\beta$-glucans consisting of a backbone of $\beta-1,3-$ D-glucose units with various lengths of $\beta-1,6$ side chains have the notable physiological effect of immunological activation (Miura et al., 1996). Immunologists have found the $\beta$-glucan receptors, dectin- 1 and complement receptor 3 , on the surface of innate immune cells (Brown and Gordon, 2001; Vetvicka et al., 2007). There are many application studies associated with $\beta$-glucan immune activation, e.g., tumoricidal activity, prevention of infection, and damage reduction of radiation exposure (Thompson et al., 2010). $\beta$-Glucans are also found to decrease the levels

\footnotetext{
${ }^{\ddagger}$ Corresponding author

* Project supported by the Fundamental Research Funds for the Central Universities of China (No. 30920130121013) and the National Natural Science Foundation of China (No. 31300111)

C Zhejiang University and Springer-Verlag Berlin Heidelberg 2014
}

of serum cholesterol and liver low-density lipoproteins, leading to lowering of atherosclerosis and cardiovascular disease hazards (Barsanti et al., 2011). Salecan, produced by the strain Agrobacterium sp. ZX09, is a novel water-soluble $\beta$-glucan-like polysaccharide. It consists of the following repeating units: $\rightarrow 3)-\beta$-D-Glcp- $(1 \rightarrow 3)$-[ $\beta$-D-Glcp-( $1 \rightarrow 3)-\beta$-D-Glcp$(1 \rightarrow 3)]_{3}-\alpha$-D-Glcp- $(1 \rightarrow 3)-\alpha$-D-Glcp- $(1 \rightarrow($ Xiu et al., 2010). This special structure of Salecan is watersoluble and has potential biological activities owing to its $\beta-1,3$-glucosides. It reduces the acute hepatic injury in mice induced by alcohol (Chen et al., 2011) and carbon tetrachloride (Chen et al., 2012). It has a potential to become a hydrophilic laxative to cure constipation (Zhou et al., 2013). It can also possibly be used in the food industry as a thickening agent due to its excellent rheological properties (Xiu et al., 2011). Therefore, increasing the yield of Salecan has a vital significance for its industrial application.

It is well known in fermentation by aerobic organisms that the supply of $\mathrm{O}_{2}$ usually becomes a 
serious limitation because of its low solubility, especially during high-cell-density fermentation or when fermentation media are highly viscous. Vitreoscilla, an obligate aerobic bacterium (Pringsheim, 1951), survives and grows in an $\mathrm{O}_{2}$-poor environment owing to its synthesis of hemoglobin ( $\mathrm{VHb}$ ). $\mathrm{VHb}$ binds $\mathrm{O}_{2}$ at low extracellular concentrations and delivers it to the terminal respiratory oxidase, thus enhancing respiration (Park et al., 2002). The vgb gene from Vitreoscilla has been successfully engineered into various organisms to improve cell density, protein synthesis, and metabolic productivity (Khosla and Bailey, 1988; Frey and Kallio, 2006; Su et al., 2010; Frey et $a l ., 2011)$. The $v g b$ gene is generally integrated into the genome of the host organisms to form stable inheritance, but this technique is usually limited to the genome-sequenced organisms.

In this study, a broad-host-range vector pCM158 (Marx and Lidstrom, 2002), hosting vgb gene, was demonstrated to persist in Salecan-producing Agrobacterium sp. ZX09 without antibiotic selection pressure and to improve the respiration rate, invertase activity, and Salecan production.

\section{Materials and methods}

\subsection{Strains, plasmids, media, and culture conditions}

Escherichia coli strain DH5 $\alpha$ was used as the host for bacterial transformation and plasmid construction. The plasmid pCM158 was used as $v g b$ expression vector, and the $v g b$ gene was derived from pUC19-vgb. Salecan-producing bacterium, Agrobacterium $\mathrm{sp}$. ZX09, was isolated from a soil sample from the ocean coast of Shandong, China (Xiu et al., 2010). The culture medium for screening transformation and producing Salecan was $\mathrm{Htm}$ composed of $\mathrm{NaH}_{2} \mathrm{PO}_{4} 1 \mathrm{~g}, \mathrm{KNO}_{3} 3 \mathrm{~g}, \mathrm{CaCl}_{2} 0.07 \mathrm{~g}, \mathrm{MgCl}_{2} 0.2 \mathrm{~g}$, $\mathrm{FeSO}_{4} \cdot 7 \mathrm{H}_{2} \mathrm{O} 0.0125 \mathrm{~g}, \mathrm{MnSO}_{4} 0.003 \mathrm{~g}, \mathrm{ZnCl}_{2} 0.0075 \mathrm{~g}$, sucrose $30 \mathrm{~g}$, and $\mathrm{H}_{2} \mathrm{O} 1000 \mathrm{ml}$, pH 7.2 (Xiu et al., 2010). The strain hosting pCM158-vgb plasmid was maintained on Htm agar medium by adding $50 \mu \mathrm{g} / \mathrm{ml}$ kanamycin. A single colony on an agar plate was first inoculated in seed medium (Htm) and aerobically incubated at $30{ }^{\circ} \mathrm{C}$ for $24 \mathrm{~h}$ with shaking at $250 \mathrm{r} / \mathrm{min}$. A $1 \%$ inoculum was added to a $250-\mathrm{ml}$ flask containing $50 \mathrm{ml}$ of medium. The flask culture was incubated at $30{ }^{\circ} \mathrm{C}$ for $72 \mathrm{~h}$ at $250 \mathrm{r} / \mathrm{min}$ and the yield of Salecan was measured after cultivation for $12,24,36,48$, and $72 \mathrm{~h}$.

\subsection{Construction of pCM158-vgb plasmid and transformation}

The $\mathrm{VHb}$ coding gene $v g b$ was first cloned from the plasmid pUC19-vgb (Khosla and Bailey, 1988) by polymerase chain reaction (PCR) with the two primers of vgb-F (AAGCTTACAGGACGCTGGGGT) and vgb-R (CAATATTTGTCCCAAGTTT). The PCR products were then cloned into pMD18-T vector to form pMD18-T-vgb, and sequenced to be correct without mutations. Last, the $v g b$ gene fragment was cut down from the pMD18-T-vgb by restriction endonucleases SphI and EcoRI, and cloned into the corresponding sites of pCM158 plasmid to form pCM158-vgb. Electrocompetent cells were prepared in super optimal broth (SOB) medium. Once the optical density at $600 \mathrm{~nm}\left(\mathrm{OD}_{600}\right)$ of the culture reached about 0.5 to 0.6 , the cells were placed on ice and washed three times with ice-cold $10 \%$ glycerol. About 100 ng of pCM158-vgb and pCM158 DNA were added to $100 \mu \mathrm{l}$ of the competent cells and the resulting mixtures were electroporated in 0.1-cm-gap cuvettes at $2.0 \mathrm{kV}, 25 \mu \mathrm{F}, 200 \Omega$ in a Gene Pulser electroporation apparatus (BioRad). Cells were resuspended in $1 \mathrm{ml} \mathrm{SOB}$ medium. The cells were allowed to recover at $30^{\circ} \mathrm{C}$ for $2 \mathrm{~h}$, and then plated on $\mathrm{Htm}$ agar plates with $50 \mu \mathrm{g} / \mathrm{ml}$ kanamycin. Strains of Agrobacterium sp. ZX09 hosting the plasmids of pCM158-vgb and pCM158 were respectively designated $\mathrm{VHb}^{+}$and $\mathrm{VHb}^{-}$. Plasmid stability was studied by inoculation of the strain into Htm medium without antibiotics and incubating at $28{ }^{\circ} \mathrm{C}$ with shaking (Guo et al., 2010). After $48 \mathrm{~h}$ of cultivation, the same amounts of cells were sprayed onto six solid medium plates: half of the plates lacked antibiotics and half contained antibiotics. Plasmid stability was indicated by the ratio of the colony-forming units (CFUs) formed on the plates with antibiotics to the ones formed on the plates without antibiotics.

\subsection{CO-difference spectral analysis of $\mathrm{VHb}$}

The $v g b$ gene expression was determined by carbon monoxide $(\mathrm{CO})$ difference spectra of $\mathrm{VHb}$ (Liu and Webster, 1974). Cells of $\mathrm{VHb}^{+}$and $\mathrm{VHb}^{-}$ were harvested from $100 \mathrm{ml}$ Htm medium after cultivation, then washed with potassium phosphate 
buffer $\left(\mathrm{KH}_{2} \mathrm{PO}_{4} 5.44 \mathrm{~g} / \mathrm{L}, \mathrm{Na}_{2} \mathrm{HPO}_{4} \cdot 12 \mathrm{H}_{2} \mathrm{O} 43 \mathrm{~g} / \mathrm{L}\right.$; $\mathrm{pH}$ 7.2), disrupted by grinding in liquid nitrogen, and resuspended in $5 \mathrm{ml}$ of potassium phosphate buffer. The cell debris was separated by centrifugation at $15000 \times \mathrm{g}$ for $5 \mathrm{~min}$. The liquid samples were exposed to $\mathrm{CO}$ for $10 \mathrm{~min}$ and then used for CO-difference spectral analysis by PowerWave HT Microplate Spectrophotometer (BioTek Instruments, Inc.).

\subsection{Analytical methods}

The viscosity of Salecan was determined by a NDJ-1 rotational viscometer (Shanghai Changji Instruments Co., Ltd., China) to indicate the relative yield of the sugar. The productivity of exopolysaccharide was expressed in terms of the weight after ethanol precipitation, collected by centrifugation, and dried under reduced pressure (Xiu et al., 2010).

The respiratory rate was determined by inoculating $1 \mathrm{ml}$ of the seed medium into a 1-L flask bottle containing $250 \mathrm{ml} \mathrm{Htm}$ medium. The bottle was sealed by a cap, and incubated at $30^{\circ} \mathrm{C}$ on a rotary shaker at $150 \mathrm{r} / \mathrm{min}$. The decrease in dissolved $\mathrm{O}_{2}$ was recorded online by an optical $\mathrm{O}_{2}$ sensor VisiFerm DO Arc 120 (Hamilton Company) inserting through the cap.

Invertase activities were measured by DNS colorimetry (Miller, 1959). Cells of $\mathrm{VHb}^{+}$and $\mathrm{VHb}^{-}$ were separated from $100 \mathrm{ml}$ culture broth by centrifugation, grinded in liquid nitrogen, and resuspended with $2 \mathrm{ml}$ sodium phosphate buffer $(0.2 \mathrm{~mol} / \mathrm{L}$ $\mathrm{NaH}_{2} \mathrm{PO}_{4} 93.5 \mathrm{ml}, 0.2 \mathrm{~mol} / \mathrm{L} \mathrm{Na}_{2} \mathrm{HPO}_{4} 6.5 \mathrm{ml}$; $\mathrm{pH}$ 5.7). A 500- $\mu \mathrm{l}$ sample of the cell suspension was mixed with $500 \mu \mathrm{l}$ of $0.1 \mathrm{~g} / \mathrm{ml}$ sucrose solution. After $10 \mathrm{~min}$, the hydrolysis was stopped by immersion of the reaction mixture in a boiling water bath for $5 \mathrm{~min}$. Glucose generated from sucrose hydrolysis by invertase was measured by DNS colorimetry. Invertase activities were expressed as milligrams of glucose per minute per milligram of protein $(\mathrm{mg} /(\mathrm{min} \cdot \mathrm{mg})$ ).

\section{Results}

\subsection{Maintenance of pCM158-vgb and its expres- sion in Agrobacterium sp. ZX09 without antibiotic selection}

The $v g b$ gene was cloned into the broad-hostrange plasmid pCM158 to form pCM158-vgb (Fig. 1), and then pCM158-vgb was successfully introduced into Agrobacterium sp. ZX09 by electroporation. The plasmid persisted well in Agrobacterium sp. ZX09. Under no antibiotic selection, there was a negligible loss of the plasmid for one passage of two days cultivation (Fig. 2), but after five passages of cultivation the loss of the plasmid was apparent. Plasmid loss is not easy as commonly thought. Velappan et al. (2007) have shown that even some incompatible plasmids could persist together in host for several passages without antibiotic selection. Persistence of plasmids in host without antibiotic selection was crucial for their practical usage in fermentation; the use of antibiotics would dramatically increase the cost of fermentation, and the waste containing the antibiotics discharged into the environment would pose serious health problems. Foreign genes were usually integrated into the genome of the host for stable propagation. However, it needs double crossover and clear genetic background of the host. The process is time-consuming, especially for non-model organisms. Another shortcoming is that the genomic-integrated foreign gene is single-copied, thus limiting the gene product. On the contrary, plasmids can overcome these shortcomings. They are multi-copied and easy to handle without the genetic background of the host. In this experiment, we showed that the broad-hostrange plasmid pCM158 can persist well in Agrobacterium sp. ZX09 without antibiotic selection at the end of cultivation and should have practical usage for the increase of product yield.

The expression of $\mathrm{VHb}$ was demonstrated by CO-difference spectrum owing to its binding to $\mathrm{CO}$. The absorbance spectrum of the solution is subtracted from the spectrum after saturation with $\mathrm{CO}$. Bubbling CO shifted the absorption maxima to $419 \mathrm{~nm}$, which are characteristic of the $\mathrm{VHb}-\mathrm{CO}$ complex. There was an absorption peak at $419 \mathrm{~nm}$ in Agrobacterium sp. ZX09 hosting pCM158-vgb $\left(\mathrm{VHb}^{+}\right)$, but it was absent in the strain hosting the empty vector pCM158 ( $\left.\mathrm{VHb}^{-}\right)$after bubbling $\mathrm{CO}$ (Fig. 3). Cells of $\mathrm{VHb}^{+}$and $\mathrm{VHb}^{-}$were collected for analysis after 2-d culturing in $\mathrm{Htm}$ medium without adding antibiotics. These results showed that $\mathrm{VHb}$ was stably expressed and further indicated that the plasmid could persist in Agrobacterium sp. ZX09 without antibiotic selection. 


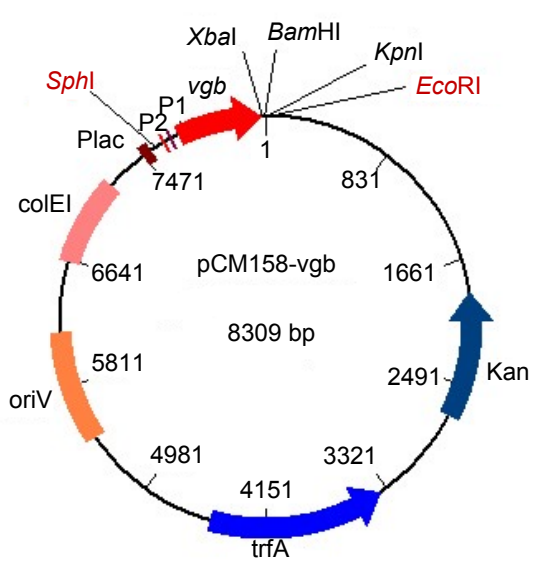

Fig. 1 Schematic map of plasmid pCM158-vgb

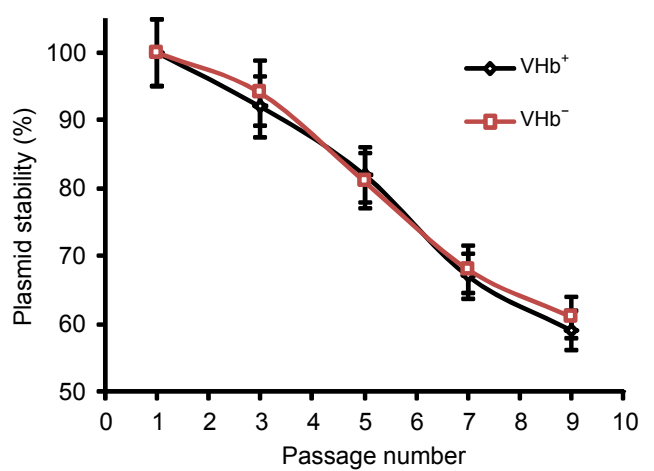

Fig. 2 pCM158 and pCM158-vgb maintenance in $\mathrm{Ag}$ robacterium sp. ZX09 without antibiotic selection One passage was defined as 48-h cultivation in Htm medium without antibiotics. Plasmid stability was indicated by the ratio of the CFUs formed on the plates with antibiotics to those formed on the plates without antibiotics. Results were averages ( \pm standard deviation) of triplicate experiments

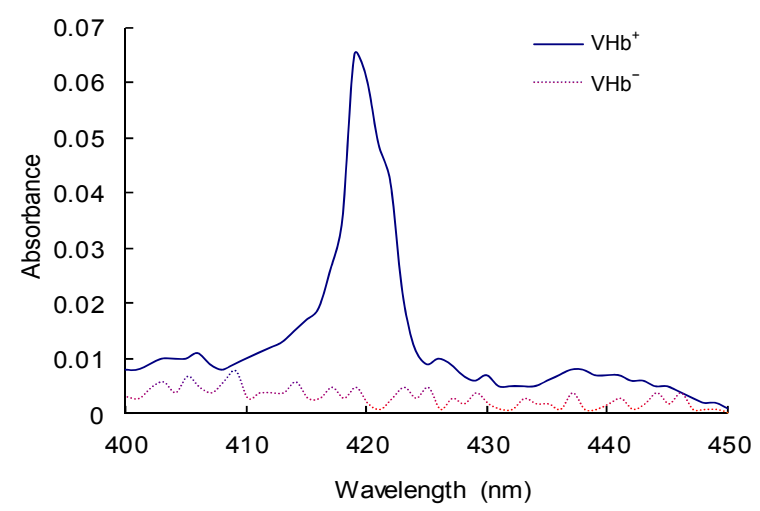

Fig. 3 CO-difference spectral analysis of $\mathrm{VHb}^{+}$and $\mathrm{VHb}^{-}$

Cells of $\mathrm{VHb}^{+}$and $\mathrm{VHb}^{-}$were collected for analysis after 2-d culturing in Htm medium without adding antibiotics

\subsection{VHb increased Salecan production}

The viscosity yields of the two strains were monitored at $12 \mathrm{~h}$ intervals for $72 \mathrm{~h}$ (Fig. 4). The viscosity of $\mathrm{VHb}^{+}$was apparently higher than that of $\mathrm{VHb}^{-}$, indicating the higher Salecan production by $\mathrm{VHb}^{+}$. At the end of fermentation, viscosity yield of $\mathrm{VHb}^{+}$was about $33 \%$ higher than that of $\mathrm{VHb}^{-}$. The obvious viscosity difference was manifested even at the first $12 \mathrm{~h}$ of the fermentation process. The Salecan production of $\mathrm{VHb}^{+}$was about $30 \%$ higher than that of $\mathrm{VHb}^{-}$(Fig. 5). Polymer synthesis is a high-energy and $\mathrm{O}_{2}$ demanding process, whereas polymer in fermentation liquid inhibits $\mathrm{O}_{2}$ transfer on account of its high viscosity. Therefore, polymer fermentation should be very sensitive to $\mathrm{O}_{2}$ supply.

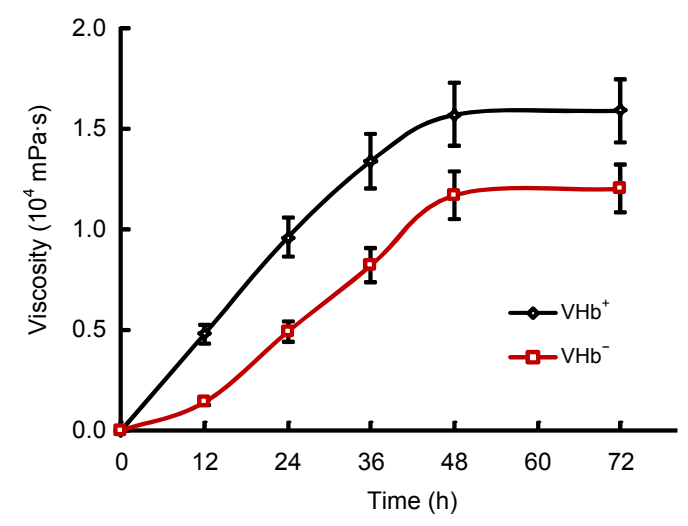

Fig. 4 Viscosity yields of $\mathrm{VHb}^{+}$and $\mathrm{VHb}^{-}$

The two strains were monitored at $12 \mathrm{~h}$ intervals for $72 \mathrm{~h}$ on a rotary shaker at $250 \mathrm{r} / \mathrm{min}$. Results were averages ( \pm standard deviation) of triplicate experiments

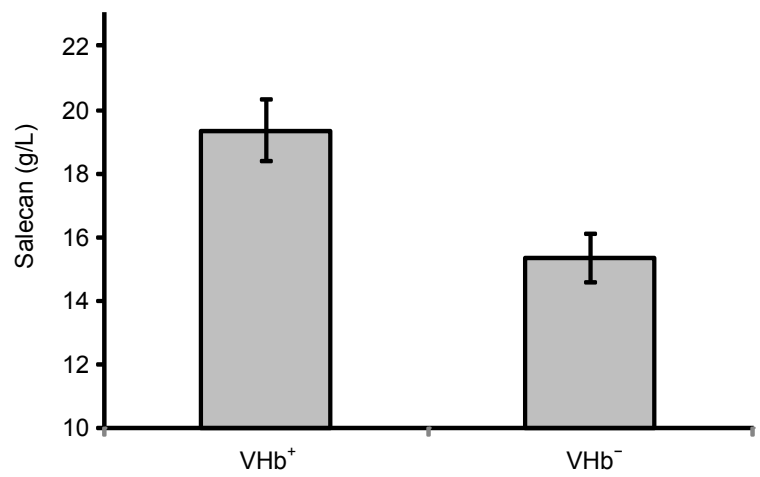

Fig. 5 Exopolysaccharide productivities of $\mathrm{VHb}^{+}$and $\mathrm{VHb}^{-}$

The fermentation was performed on a rotary shaker at $250 \mathrm{r} / \mathrm{min}$ for $48 \mathrm{~h}$. Results are averages ( \pm standard deviation) of triplicate experiments 


\section{3 $\mathrm{VHb}$ increased respiration rate}

The $\mathrm{O}_{2}$ concentration in the liquid was monitored online in a sealed bottle. In order to set off the effect of cell concentration, the same amounts of $\mathrm{VHb}^{+}$ and $\mathrm{VHb}^{-}$were inoculated, and at the end of the experiment, the $\mathrm{OD}_{600}$ values of the cells were measured to be 0.048 and 0.046 , respectively, for $\mathrm{VHb}^{+}$and $\mathrm{VHb}^{-}$, a difference of less than $5 \%$. In general, the two curves had a similar pattern of $\mathrm{O}_{2}$ decreasing rate (Fig. 6a), but at different $\mathrm{O}_{2}$ concentrations the consumption rates varied. The lower the $\mathrm{O}_{2}$ concentration was, the $\mathrm{VHb}^{+}$consumed $\mathrm{O}_{2}$ at a higher rate. At the interval of $20 \%-40 \%, 6 \%-10 \%$, and $3 \%-6 \%$ air saturated $\mathrm{O}_{2}$ concentration, the relative respiration rates of $\mathrm{VHb}^{+}$were $0.236,0.082$, and 0.065 , respectively, while the values for $\mathrm{VHb}^{-}$were $0.194,0.042$, and 0.022 (Figs. 6b-6d). Both $\mathrm{VHb}^{+}$and $\mathrm{VHb}^{-}$dropped their respiration rates with the decrease of $\mathrm{O}_{2}$ concentration, but with different dropping rates. $\mathrm{VHb}^{+}$ consumed $\mathrm{O}_{2}$ faster than $\mathrm{VHb}^{-}$. At the three $\mathrm{O}_{2}$ concentration intervals, the respiration rates of $\mathrm{VHb}^{+}$ were 1.2, 1.9, and 3.1-fold that of $\mathrm{VHb}^{-}$, respectively. While at the interval of $40 \%-100 \%$ air saturated $\mathrm{O}_{2}$
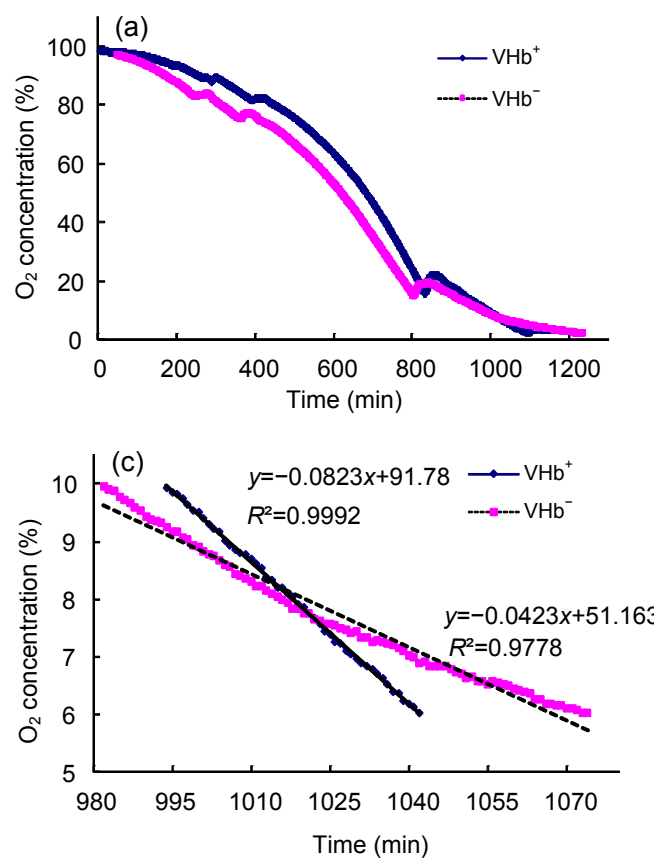

concentration, the difference of respiration rate between $\mathrm{VHb}^{+}$and $\mathrm{VHb}^{-}$was not obvious (data not shown). The growth limiting $\mathrm{O}_{2}$ concentrations for bacteria are usually far below air saturated $\mathrm{O}_{2}$ concentration. Above the growth limiting $\mathrm{O}_{2}$ concentrations, the terminal oxidase is saturated by $\mathrm{O}_{2}$ and the reaction will not increase with the rise of $\mathrm{O}_{2}$ concentrations. This explains why at high $\mathrm{O}_{2}$ concentration of $20 \%-40 \%$ the respiration rates of $\mathrm{VHb}^{+}$and $\mathrm{VHb}^{-}$ were similar; at very low $\mathrm{O}_{2}$ concentration, $\mathrm{VHb}$ played a significant role in facilitating its host respiration. The localization of $\mathrm{VHb}$ was determined to be concentrated near the cell membrane (Ramandeep et al., 2001), and further study showed that VHb could bind the subunit I of cytochrome bo and provide $\mathrm{O}_{2}$ directly to the terminal oxidase (Park et al., 2002), thus providing $\mathrm{O}_{2}$ directly to the terminal oxidase.

\section{4 $\mathrm{VHb}$ increased cellular invertase activity}

The increase in respiration rate and product yield means more rapid carbon drainage and conversion. Since sucrose was the sole carbon source for Agrobacterium sp. ZX09, we measured the activity of the sucrose hydrolase enzyme invertase. The cellular
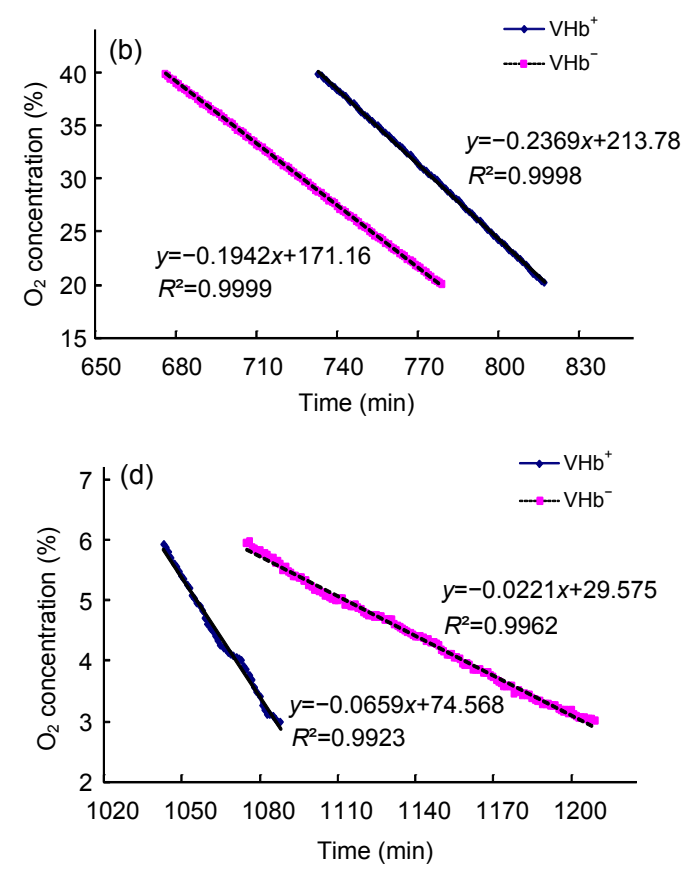

Fig. 6 Respiration rates of $\mathrm{VHb}^{+}$and $\mathrm{VHb}^{-}$

(a) In general, $\mathrm{VHb}^{+}$and $\mathrm{VHb}^{-}$had a similar pattern of $\mathrm{O}_{2}$ decreasing rate. The $\mathrm{O}_{2}$ concentration in the liquid was monitored online in a sealed bottle. In order to set off the effect of cell concentration, the same amounts of $\mathrm{VHb}^{+}$and $\mathrm{VHb}^{-}$were inoculated. (b-d) Respiration rates at 20\%-40\% (b), 6\%-10\% (c), and 3\%-6\% (d) air saturated $\mathrm{O}_{2}$ concentration interval. These formulae indicate the linear regression of the data. The coefficients indicate the change rate of $\mathrm{O}_{2}$ concentration $(y)$ with respect to time $(x) . R^{2}$, the statistic parameter, measures the goodness of model fitting, with the value of 1 as perfect fitting 


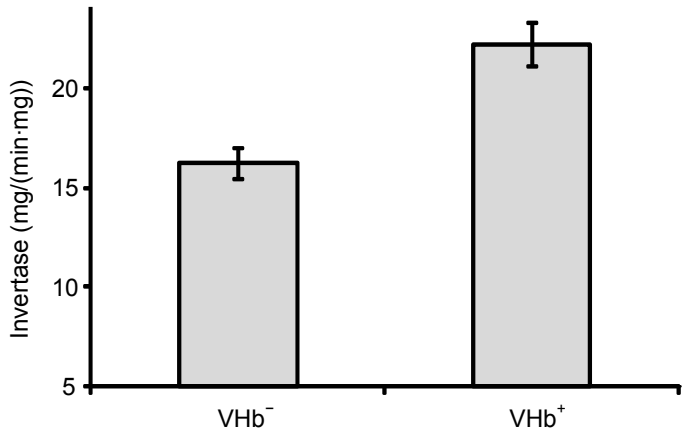

Fig. 7 Invertase activities of $\mathrm{VHb}^{+}$and $\mathrm{VHb}^{-}$ Invertase activity was expressed as milligram of glucose per minute per milligram of protein $(\mathrm{mg} /(\mathrm{min} \cdot \mathrm{mg}))$. Results are averages ( \pm standard deviation) of triplicate experiments

invertase activity in $\mathrm{VHb}^{+}$increased $37 \%$ compared with $\mathrm{VHb}^{-}$strain (Fig. 7). It was reported that overexpression of invertase in plants increased oxygen consumption (Bologa et al., 2003). Therefore, the increase in respiration of $\mathrm{VHb}^{+}$was probably caused in part by the increase in invertase activity. The mechanism for the increase in invertase activity was unclear, though there were similar reports that the expression of invertase was suppressed under low $\mathrm{O}_{2}$ concentration (Zeng et al., 1999; Bologa et al., 2003).

\section{Conclusions}

In order to overcome the $\mathrm{O}_{2}$ limiting during Salecan fermentation, we cloned the Vitreoscilla hemoglobin gene, $v g b$, into a broad-host-range plasmid pCM158 to form pCM158-vgb. The plasmid could persist in the host Agrobacterium sp. ZX09 for at least one passage without antibiotic selection. The engineered strain Agrobacterium sp. ZX09 increased Salecan yield by $30 \%$ without antibiotic selection pressure. The benefit for the approach is its ease of handling and usefulness for field fermentation.

\section{Acknowledgements}

We would like to thank Mary E. LIDSTROM from the University of Washington, USA for providing the plasmid pCM158.

\section{Compliance with ethics guidelines}

Yun-mei CHEN, Hai-yang XU, Yang WANG, Jian-fa ZHANG, and Shi-ming WANG declare that they have no conflict of interest.
This article does not contain any studies with human or animal subjects performed by any of the authors.

\section{References}

Barsanti, L., Passarelli, V., Evangelista, V., et al., 2011. Chemistry, physico-chemistry and applications linked to biological activities of $\beta$-glucans. Nat. Prod. Rep., 28(3): 457-466. [doi:10.1039/c0np00018c]

Bologa, K.L., Fernie, A.R., Leisse, A., et al., 2003. A bypass of sucrose synthase leads to low internal oxygen and impaired metabolic performance in growing potato tubers. Plant Physiol., 132(4):2058-2072. [doi:10.1104/pp.103. 022236]

Brown, G.D., Gordon, S., 2001. Immune recognition. A new receptor for $\beta$-glucans. Nature, 413(6851):36-37. [doi:10. 1038/35092620]

Chen, P., Wang, Z., Zeng, L., et al., 2011. A novel soluble $\beta$-glucan Salecan protects against acute alcohol-induced hepatotoxicity in mice. Biosci. Biotechnol. Biochem., 75(10):1990-1993. [doi:10.1271/bbb.110412]

Chen, P., Wang, Z., Zeng, L., et al., 2012. Protective effects of Salecan against carbon tetrachloride-induced acute liver injury in mice. J. Appl. Toxicol., 32(10):796-803. [doi:10.1002/jat.1694]

Frey, A.D., Kallio, P.T., 2006. Bacterial hemoglobins and flavohemoglobins: versatile proteins and their impact on microbiology and biotechnology. FEMS Microbiol. Rev., 27(4):525-545. [doi:10.1016/S0168-6445(03)00056-1]

Frey, A.D., Shepherd, M., Jokipii-Lukkari, S., et al., 2011. The single-domain globin of Vitreoscilla: augmentation of aerobic metabolism for biotechnological applications. Advan. Microb. Physiol., 58:81-139. [doi:10.1016/B9780-12-381043-4.00003-9]

Guo, Q., Zhang, W., Ma, L.L., et al., 2010. A food-grade industrial arming yeast expressing $\beta$-1,3-1,4-glucanase with enhanced thermal stability. J. Zhejiang Univ.-Sci. B (Biomed. \& Biotechnol.), 11(1):41-51. [doi:10.1631/jzus. B0900185]

Khosla, C., Bailey, J.E., 1988. The Vitreoscilla hemoglobin gene: molecular cloning, nucleotide sequence and genetic expression in Escherichia coli. Mol. Gen. Genet., 214(1): 158-161. [doi:10.1007/BF00340195]

Liu, C.Y., Webster, D.A., 1974. Spectral characteristics and interconversions of the reduced oxidized, and oxygenated forms of purified cytochrome o. J. Biol. Chem., 249(13): 4261-4266.

Marx, C.J., Lidstrom, M.E., 2002. Broad-host-range cre-lox system for antibiotic marker recycling in Gram-negative bacteria. Biotechniques, 33(5):1062-1067.

Miller, G.L., 1959. Use of dinitrosalicylic acid reagent for determination of reducing sugar. Anal. Chem., 31(3): 426-428. [doi:10.1021/ac60147a030]

Miura, N.N., Ohno, N., Aketagawa, J., et al., 1996. Blood clearance of $(1 \rightarrow 3)-\beta$-D-glucan in MRL lpr/lpr mice. FEMS Immunol. Med. Microbiol., 13(1):51-57. [doi:10. 1111/j.1574-695X.1996.tb00215.x] 
Park, K.W., Kim, K.J., Howard, A.J., et al., 2002. Vitreoscilla hemoglobin binds to subunit I of cytochrome bo ubiquinol oxidases. J. Biol. Chem., 277(36):33334-33337. [doi:10. 1074/jbc.M203820200]

Pringsheim, E.G., 1951. The Vitreoscillaceae: a family of colourless, gliding, filamentous organisms. J. Gen. Microbiol., 5(1):124-149. [doi:10.1099/00221287-5-1-124]

Ramandeep, Hwang, K.W., Raje, M., et al., 2001. Vitreoscilla hemoglobin. Intracellular localization and binding to membranes. J. Biol. Chem., 276(27):24781-24789. [doi:10. 1074/jbc.M009808200]

Su, Y., Li, X., Liu, Q., et al., 2010. Improved poly- $\gamma$-glutamic acid production by chromosomal integration of the Vitreoscilla hemoglobin gene $(\mathrm{vgb})$ in Bacillus subtilis. Bioresource Technol., 101(12):4733-4736. [doi:10.1016/ j.biortech.2010.01.128]

Thompson, I.J., Oyston, P.C., Williamson, D.E., 2010. Potential of the $\beta$-glucans to enhance innate resistance to biological agents. Expert Rev. Anti-Infect. Ther., 8(3): 339-352. [doi:10.1586/eri.10.10]

Velappan, N., Sblattero, D., Chasteen, L., et al., 2007. Plasmid incompatibility: more compatible than previously thought? Protein Eng. Des. Sel., 20(7):309-313. [doi:10.1093/ protein/gzm005]
Vetvicka, V., Dvorak, B., Vetvickova, J., et al., 2007. Orally administered marine $(1 \rightarrow 3)-\beta$-D-glucan Phycarine stimulates both humoral and cellular immunity. Int. J. Biol. Macromol., 40(4):291-298. [doi:10.1016/j.ijbiomac. 2006. 08.009]

Xiu, A., Kong, Y., Zhou, M., et al., 2010. The chemical and digestive properties of a soluble glucan from Agrobacterium sp. ZX09. Carbohyd. Polym., 82(3):623-628. [doi:10. 1016/j.carbpol.2010.05.027]

Xiu, A., Zhou, M., Zhu, B., et al., 2011. Rheological properties of Salecan as a new source of thickening agent. Food Hydrocolloids, 25(7):1719-1725. [doi:10.1016/j.foodhyd. 2011.03.013]

Zeng, Y., Wu, Y., Avigne, W.T., et al., 1999. Rapid repression of maize invertases by low oxygen. Invertase/sucrose synthase balance, sugar signaling potential, and seedling survival. Plant Physiol., 121(2):599-608. [doi:10.1104/ pp.121.2.599]

Zhou, M., Jia, P., Chen, J., et al., 2013. Laxative effects of Salecan on normal and two models of experimental constipated mice. BMC Gastroenterol., 13:52. [doi:10. 1186/1471-230X-13-52]

\section{中文㩯要：}

\section{本文题目：在土壤杆菌 ZX09 中透明颤菌血红蛋白的表达提高索拉胶的产量}

Vitreoscilla hemoglobin promotes Salecan production by Agrobacterium sp. ZX09

研究目的：提高胞外多糖索拉胶的产量。

创新要点：透明颤菌血红蛋白基因在质粒上表达，不加抗生素发酵生产索拉胶。

研究方法: 将透明颤菌血红蛋白基因构建到广谱质粒 $\mathrm{pCM} 158$ 上得到重组质粒 $\mathrm{pCM} 158$ - vgb, 重组质粒转

入土壤杆菌 ZX09 中，使透明颤菌血红蛋白在土壤杆菌 ZX09 中表达。

重要结论: 在土壤杆菌 ZX09 中颤菌血红蛋白的表达解决了发酵过程中氧受限的问题, 提高了宿主菌的 呼吸速率、蔗糖酶活性和黏度，将发酵产物索拉胶的产量提高了 $30 \%$ 。

关键词组：索拉胶；透明颤菌血红蛋白；土壤杆菌 ZX09；蔗糖酶；呼吸速率 